\title{
The role of serum HDL, LDL, and uric acid levels in predicting the prognosis of community-acquired pneumonia
}

\author{
Serum HDL, LDL ve ürik asit düzeyinin toplum kökenli pnömönide prognoz \\ tahminindeki rolü \\ Derya Hoşgün, Evrim Eylem Akpınar, Esen Sayın Gülensoy, Can Ateş, Nalan Ogan, Berçem Afşar \\ Karatepe
}

Gönderilme tarihi:29.01.2021

Kabul tarihi:20.05.2021

\begin{abstract}
Purpose: Community-acquired pneumonia (CAP) leads to inflammation and oxidative stress as a result in infection. In the present study, we aimed to investigate the relationship between initial serum high-density lipoprotein (HDL), low-density lipoprotein (HDL), and uric acid levels on short-term (30-day) changes in the course of CAP.

Materials and methods: The retrospective study included 113 patients with CAP that received inpatient care between 2012 and 2018. The HDL, LDL and uric acid values in the blood received in hospital admission were examined for their relationship with short-term mortality and correlation with hospitalization.

Results: The 113 patients comprised $71(62.8 \%)$ men and $42(37.2 \%)$ women with a mean age of $74 \pm 11$ years. Of the 113 patients, 30-day mortality occurred in $12(10.6 \%)$ patients. Of the 113 patients, $17(16.5 \%)$ patients were hospitalized in ICU. All cases detected as mortality were followed in ICU. Normal ranges of HDL, LDL, and uric acid concentrations were accepted as $40-70 \mathrm{mg} / \mathrm{dL}, 60-130 \mathrm{mg} / \mathrm{dL}$, and 1.8-8 mg/dL, respectively. The mean serum LDL, HDL, and uric acid levels were $97.95 \pm 42.11$ (range, 26-271) mg/dL, 40.94 \pm 13.70 (range, $5.10-83.20) \mathrm{mg} / \mathrm{dL}$, and $5.99 \pm 2.18$ (range, 1.40-13.20) $\mathrm{mg} / \mathrm{dL}$, respectively. HDL and LDL levels were found to be insignificant predictors of 30 -day mortality ( $p=0.482$ and $p=0.725$, respectively). Similarly, serum HDL, LDL, and uric acid levels were found to be insignificant predictors of the duration of hospitalization and ICU requirement. On the other hand, multivariate logistic regression analysis indicated that uric acid concentration was a protective factor for 30 -day mortality (OR, $0.694 ; 95 \% \mathrm{Cl}, 0.478-0.989, p=0.048)$, whereby increased uric acid concentration was found to decrease the risk of mortality and reduced uric acid concentration was found to increase the risk of mortality by 1.44 times (1/0.694).

Conclusion: We suggest that monitoring uric acid levels with serial measurements in patients with CAP may be useful for predicting the short term prognosis. Further prospective multicentric studies with larger patient series are needed to investigate the correlation between serum uric acid levels and clinical risk scores.
\end{abstract}

Key words: CAP, HDL, LDL, uric acid.

Hosgun D, Akpinar EE, Sayin Gulensoy E, Ates C, Ogan N, Afsar Karatepe B. The role of serum HDL, LDL, and uric acid levels in predicting the prognosis of community-acquired pneumonia. Pam Med J 2022;15:15-22.

Öz

Amaç: Toplum kökenli pnömonide (TKP) enfeksiyona bağlı inflamasyon ve oksidatif stres oluşmaktadır. Bu çalışmamızda amacımız; başlangıç yüksek dansiteli lipoprotein (HDL), düşük dansiteli lipoprotein (LDL) ve ürik asit serum düzeylerinin TKP'de kısa dönem (30 gün) hastalık sürecindeki değişikliklerle ilişkisini değerlendirmektir. Gereç ve yöntem: 2012-2018 tarihleri arasında hastaneye yatırılarak tedavi edilen 113 TKP olgusu retrospektif olarak değerlendirildi. Hastaneye başvuru esnasındaki ilk 24 saatte ölçülen HDL, LDL ve ürik asit düzeyleri incelendi. Hastane kabulünde alınan kandaki HDL, LDL ve ürik asit değerlerinin kısa dönem mortaliteyle ilişkisi ve hospitalizasyonla korelasyonunu araştırıldı.

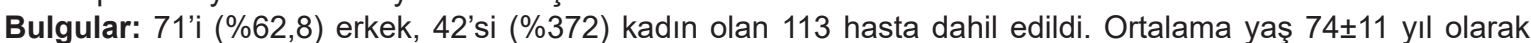
bulundu. Otuz günlük mortalite oranı \%10,6 (113 hastanın 12'sinde) olarak saptandı. Yoğun bakım yatış oranı \%15 olarak (113 hastanın 17'sinde) tespit edildi. Mortalite saptanan tüm vakaların yoğun bakımda takip edildiği

Derya Hoşgün, MD. Atatürk Chest Diseases and Chest Surgery Education and Research, Hospital Department of Intensive Care Unit, Ankara, Turkey e-mail: deryahosgun@gmail.com (https://orcid.org/0000-0001-1221-3620) (Corresponding Author)

Evrim Eylem Akpınar, Prof. MD. Ufuk University School of Medicine, Department of Pulmonary Medicine, Ankara, Turkey, e-mail: drevrimeylem@ gmail.com (https://orcid.org/0000-0001-9040-9309)

Esen Sayın Gülensoy, Asst. Prof. Ufuk University School of Medicine, Department of Pulmonary Medicine, Ankara, Turkey, e-mail: esen_sayin@ hotmail.com (https://orcid.org/0000-0002-2671-4584)

Can Ateş, Asst. Prof. Aksaray University Faculty of Medicine Department of Biostatistics, Aksaray, Turkey, e-mail: can.ates@gmail.com (https:// orcid.org/0000-0003-2286-4398)

Nalan Ogan, Asst. Prof. Ufuk University School of Medicine, Department of Pulmonary Medicine, Ankara, Turkey, e-mail: nalanogan@gmail. com (https://orcid.org/0000-0001-5232-3803)

Berçem Afşar Karatepe, MD. Elazıg Fethi Sekin City Hospital, Department of Internal Medicine, Elazıg, Turkey, e-mail: drbercem@hotmail.com (https://orcid.org/0000-0002-6772-8827) 
tespit edildi. HDL, LDL ve ürik asit konsantrasyon normal aralığı sırasıyla 40-70 mg/dL, 60-13 mg/dL ve 1,8-8 mg/dL olarak kabul edilirken; kan serum LDL, HDL ve ürik asit serum düzeylerimiz sırasıyla 97,95 $\pm 42,11 \mathrm{mg} /$

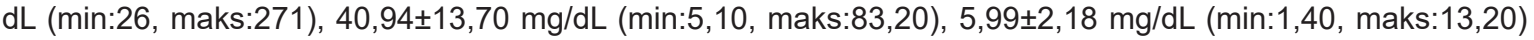
bulundu. HDL ve LDL düzeyleri istatiksel olarak anlamlı saptanmadı ( $p=0,482, p=0,725)$. HDL, LDL ve ürik asit düzeylerinin klinik yatış süresi ve yoğun bakım ihtiyacını öngörmede ilişkisi istatiksel olarak anlamlı değildi. Çoklu değişkenli logistik regresyon analizde ürik asit düzeyi koruyucu faktör olarak tespit edildi (OR, 0,694; $\% 95 \mathrm{Cl}, 0,478-0,989, p=0,048)$. Sonuçta ürik asitin artması mortalite riski azaltırken; düşük ürik asit düzeyleri $(1 / 0,694) 1,44$ kat mortalite olasılığını artırmaktadır.

Sonuç: TKP'de kısa dönem prognoz takibinde serum ürik asit düzeylerinin seri ölçümlerle takip edilmesinin faydalı olabileceği düşünülmüştür. Serum ürik asit düzeyinin TKP'de klinik risk skorlamalarında yer alması için çok merkezli, gözlemsel çalışmalar yapılmalıdır.

Anahtar kelimeler: TKP, HDL, LDL, ürik asit.

Hoşgün D, Akpınar EE, Sayın Gülensoy E, Ateş C, Ogan N, Afşar Karatepe B. Serum HDL, LDL ve ürik asit düzeyinin toplum kökenli pnömönide prognoz tahminindeki rolü. Pam Tıp Derg 2022;15:15-22.

\section{Introduction}

High-density lipoprotein (HDL), low-density lipoprotein (LDL), and very-low -density lipoprotein (VLDL) are the most significant lipoproteins in plasma. Elevated triglyceride concentrations, reduced HDL-cholesterol (HDL-C) concentration rates, in particular, are known as significant risk factors for atherosclerosis. Previous studies suggested that clinical conditions such as acute infection are effective on lipid metabolism [1, 2]. Moreover, it has also been suggested that gramnegative infections (Chlamydia pneumonia) predominantly affect triglyceride and HDL levels [1]. On the other hand, reduced lipid concentration is known to be a prognostic factor in critical diseases such as sepsis [2].

Uric acid is produced by endogenous sources including vascular endothelium, liver and kidneys. It has been found that the level of uric acid increases in the case of oxidative stress, thereby indicating its antioxidant and proinflammatory effects. The most important antioxidant effect occurs by neutralizing free radicals in serum $[3,4]$.

Community-acquired pneumonia (CAP) is a clinical condition caused by infectious diseases and also a leading cause of mortality and morbidity. CAP is often accompanied by infection-associated inflammation and oxidative stress [5]. To date, a variety of scoring systems [(Confusion Urea Respiratory Rate Blood Pressure-65 (CURB-65) and pneumonia severity index (PSI)] and biochemical markers (c-reactive protein, procalcitonin) have been used in the assessment of hospitalization, mortality and prognosis in CAP patients. However, although uric acid concentration has been shown to be correlated with the severity, prognosis, and incidence of respiratory diseases, there is no clear evidence regarding the effect of lipid concentration on the prognosis of these diseases [2, 6]. Moreover, some previous studies found reduced HDL levels in CAP patients [7, 8]. The aim of this study was to investigate the relationship between initial serum HDL, LDL, and uric acid levels on shortterm (30-day) changes in the course of CAP.

\section{Materials and methods}

The retrospective study included 113 patients with CAP that received inpatient care between 2012 and 2018. After obtaining an approval from the local ethics committee (Ufuk University Non-Interventional Clinical Research approved by the Ethics Committee), clinical records including laboratory findings, hospital discharge reports, and 30-day mortality records were retrieved from hospital databases. The HDL, LDL and uric acid levels of the patients were measured within the first 24 hours after hospital admission. Inclusion criteria were as follows: a diagnosis of CAP based on the British Thoracic Society (BTS) and American Thoracic Society (ATS) guidelines, a history of treatment at the inpatient service or intensive care unit (ICU), and a CURB-65 and PSI score [9-11]. Exclusion criteria were as follows: pregnancy, active systemic diseases, infections other than CAP, acute or chronic kidney disease, chronic lung disease, chronic obstructive pulmonary disease (COPD), active malignancy, use of drugs that could affect HDL, LDL, and uric acid concentrations and a diagnosis of connective tissue disease or vasculitis. HDL, LDL, and uric acid concentrations were assessed spectrophotometrically using an Abbot C8000 
device. Normal ranges of HDL, LDL, and uric acid concentrations were accepted as 40$70 \mathrm{mg} / \mathrm{dL}, 60-130 \mathrm{mg} / \mathrm{dL}$, and $1.8-8 \mathrm{mg} / \mathrm{dL}$, respectively.

\section{Statistical analysis}

Statistical analyses were performed using SPSS for Windows version 23.0 (IBM SPSS Inc., Armonk, NY, USA). Descriptives were expressed as frequencies $(n)$, percentages (\%), mean \pm standard deviation (SD), and median (minimum-maximum). Normal distribution of data was assessed using KolmogorovSmirnov and Shapiro Wilk tests. Homogeneity of variances was tested by Levene's test. Continuous variables were compared using Student's $t$-test or Mann-Whitney $U$ test and categorical variables were compared using Chisquare test. Correlations between variables were determined using Spearman's Correlation Coefficient. Factors affecting the 30-day mortality were determined using univariate and multiple analyses of logistic regression. ROC curves were constructed to illustrate the sensitivity and specificity performance of HDL, LDL, and uric acid levels on ICU requirement. A $p$ value of $<0.05$ was considered significant.

\section{Results}

The 113 patients comprised $71(62.8 \%)$ men and $42(37.2 \%)$ women with a mean age of $74 \pm 11$ years. Of the 113 patients, 30-day mortality occurred in 12 (10.6\%) patients. All mortality developing patients were observed in ICU. In the 17 patients that were hospitalized in ICU, mean APACHE II score was 26.36 \pm 5.03 and the expected mortality rate was $52.86 \pm 21.65$. In all patients, mean hospital stay was $6.92 \pm 3.08$ days. Table 1 presents the demographic characteristics, 30-day mortality, duration of ICU and hospital stay, and CURB-65 and PSI scores for all patients. Mean serum LDL, HDL, and uric acid levels were 97.95 \pm 42.11 (range, 26-271) $\mathrm{mg} / \mathrm{dL}, 40.94 \pm 13.70$ (range, 5.10-83.20) mg/ $\mathrm{dL}$, and $5.99 \pm 2.18$ (range, 1.40-13.20) $\mathrm{mg} / \mathrm{dL}$, respectively (Table 2 ).

In univariate logistic regression analysis CURB-65 scores was found to be significant factors affecting 30-day mortality $(p<0.001)$ while HDL, LDL and uric acid levels were found to be insignificant factors $(p=0.482, p=0.117$ and $p=0.725$, respectively). In multivariate logistic regression analysis, uric acid concentration was found to be a protective factor (OR, 0.694; 95\%

Table 1. Demographic and clinical characteristics

\begin{tabular}{|c|c|c|c|}
\hline \multicolumn{3}{|l|}{ Variables } & \multirow{2}{*}{$\begin{array}{l}\mathbf{n}(\%) \\
71(62.8) \\
42(37.2)\end{array}$} \\
\hline Gender & $\begin{array}{l}\text { Male } \\
\text { Female }\end{array}$ & & \\
\hline Mortality & $\begin{array}{l}\text { Yes } \\
\text { No }\end{array}$ & & $\begin{array}{l}12(10.6) \\
101(89.4)\end{array}$ \\
\hline ICU reguirement & $\begin{array}{l}\text { Yes } \\
\text { No }\end{array}$ & & $\begin{array}{l}17(15) \\
96(85)\end{array}$ \\
\hline CURB-65 & $\begin{array}{l}2 \\
3 \\
4 \\
5\end{array}$ & & $\begin{array}{l}49(43.4) \\
55(48.7) \\
8(7.1) \\
1(0.9)\end{array}$ \\
\hline PSI score & $\begin{array}{l}2 \\
3 \\
4 \\
5\end{array}$ & & $\begin{array}{l}20(17.7) \\
55(48.7) \\
37(32.7) \\
3(2.7)\end{array}$ \\
\hline Variables & Mean $\pm S D$ & Median & Min-Max \\
\hline Age (years) & $74 \pm 11$ & 75 & $39.00-94.00$ \\
\hline Duration of hospitalization & $6.92 \pm 3.08$ & 7.00 & $1.00-16.00$ \\
\hline $\begin{array}{l}\text { APACHE II } \\
\text { Expected mortality rate }\end{array}$ & $\begin{array}{l}26.36 \pm 5.03 \\
52.86 \pm 21.65\end{array}$ & $\begin{array}{l}26.50 \\
51.35\end{array}$ & $\begin{array}{l}19.00-35.00 \\
3.80-83.10\end{array}$ \\
\hline CURB-65 & $2.65 \pm 0.65$ & 3.00 & $2.00-5.00$ \\
\hline PSI & $3.20 \pm 0.76$ & 3.00 & $2.00-5.00$ \\
\hline
\end{tabular}

ICU: Intensive care unit, CURB-65: Confusion Urea Respiratory Rate Blood Pressure-65, PSI: Pneumonia severity index, SD: Standard deviation 
Table 2. LDL, HDL and uric acid levels

\begin{tabular}{llll}
\hline Variables & Mean \pm SD & Median & Min-Max \\
\hline LDL & $97.95 \pm 42.11$ & 93.00 & $26.00-271.00$ \\
HDL & $40.94 \pm 13.70$ & 40.00 & $5.10-83.00$ \\
Uric acid & $5.99 \pm 2.18$ & 6.00 & $1.40-13.20$ \\
\hline
\end{tabular}

LDL: Low-density lipoprotein

HDL: High-density lipoprotein

$\mathrm{Cl}, 0.478-0.989, p=0.048)$, whereby increased uric acid concentration was found to decrease the risk of mortality and reduced uric acid concentration was found to increase the risk of mortality by 1.44 times $(1 / 0.694)$ (Table 3$)$.

On the other hand, PSI and CURB-65 scores and HDL, LDL, and uric acid concentrations were found to have no insignificant effect on the duration of hospitalization $(p=0.195$, $p=0.662, \quad p=0.917, \quad p=0.080$ and $p=0.996$ ) (Table 4). Similarly, no significant difference was found between mortality and non-mortality groups with regard to LDL, HDL, and uric acid concentrations $(p=0.592, p=0.479$ and $p=0.132)$ (Table 5) (Figure 1).
Uric acid, LDL, and HDL concentrations were found to be insignificant predictors of ICU requirement due to the small number of patients hospitalized in ICU ( $p=0.109, p=0.472$, and $p=0.472$, respectively) (Figure 2). Similarly, CURB-65 and PSI scores were found to be significant predictors of ICU requirement in CAP ( $p=0.005$ and $p=0.007$, respectively).

\section{Discussion}

The current retrospective, single-centered study evaluated the correlation between HDL, LDL, and uric acid concentrations and 30-day mortality, duration of hospitalization, and ICU requirement in 113 patients with CAP so that

Table 3. Effect of CURB-65 scores, HDL, LDL, and uric acid levels inpredicting 30-day mortality

\begin{tabular}{llllll}
\hline Univariate Logistic Regression analysis & & & \\
\hline Variables & B & Standard Error & $\begin{array}{l}\text { Odds } \\
\text { ratio }\end{array}$ & $\begin{array}{l}\text { 95\% Confidence Interval (CI) } \\
\text { Lower limit - Upper limit }\end{array}$ & $\boldsymbol{p}$ \\
\hline CURB-65 & 2.057 & 0.582 & 7.820 & $2.496-24.502$ & $<0.001$ \\
HDL & -0.017 & 0.024 & 0.983 & $0.939-1.030$ & 0.482 \\
LDL & -0.003 & 0.008 & 0.997 & $0.983-1.020$ & 0.725 \\
Uric acid & -0.257 & 0.164 & 0.773 & $0.561-1.067$ & 0.117 \\
Multiple Logistic & Regression Analysis & & & $\boldsymbol{p}$ \\
Variables & $\mathrm{B}$ & Standard Error & Odds ratio & $95 \%$ Confidence Interval (Cl) & \\
\multicolumn{7}{l}{ CURB-65 } & 2.249 & 0.633 & 9.447 & $2.742-32.756$ & $<0.001$ \\
Uric acid & -0.365 & 0.185 & 0.694 & $0.478-0.989$ & 0.048 \\
\hline
\end{tabular}

LDL: Low-density lipoprotein, HDL: High-density lipoprotein,

CURB-65: Confusion Urea Respiratory Rate Blood Pressure-65

Table 4. Effect of PSI, CURB-65 scores and HDL, LDL, and uric acid levels on the duration of hospitalization

\begin{tabular}{|c|c|c|c|c|c|}
\hline $\begin{array}{l}\text { Spearman's } \\
\text { Rho (r;p) }\end{array}$ & LDL & HDL & Uric acid & PSI & CURB-65 \\
\hline $\begin{array}{l}\text { Duration of } \\
\text { hospitalization } \\
(n=103)\end{array}$ & $\begin{array}{l}-0172 \\
0.080\end{array}$ & $\begin{array}{l}0.010 \\
0.917\end{array}$ & $\begin{array}{l}0.001 \\
0.996\end{array}$ & $\begin{array}{l}0.128 \\
0.195\end{array}$ & $\begin{array}{l}-0.043 \\
0.662\end{array}$ \\
\hline
\end{tabular}

LDL: Low-density lipoprotein, HDL: High-density lipoprotein, CURB-65: Confusion Urea Respiratory Rate Blood Pressure-65, PSI: Pneumonia severity index 
Table 5. HDL, LDL, and uric acid levels mortality and non-mortality groups

\begin{tabular}{|c|c|c|c|}
\hline \multirow{2}{*}{ Variables } & non-mortality & mortality & $p$ \\
\hline & Mean $\pm S D-[M e d i a n-(M i n-M a x)]$ & Mean $\pm S D-[M e d i a n-(M i n-M a x)]$ & \\
\hline LDL & $98.43 \pm 41.43-[93.00(26.00-271.00)]$ & $93.93 \pm 49.23-80.96[(35.00-181.00)]$ & 0.592 \\
\hline HDL & $41.25 \pm 13.25-[40.00(16.90-83.20)]$ & $38.31 \pm 17.47-[38.25(5.10-76.98)]$ & 0.479 \\
\hline Uric acid & $6.10 \pm 2.15-[6.00(1.40-13.30)]$ & $5.05 \pm 2.22-[4.18(2.80-8.90)]$ & 0.132 \\
\hline
\end{tabular}

LDL: Low-density lipoprotein, HDL: High-density lipoprotein

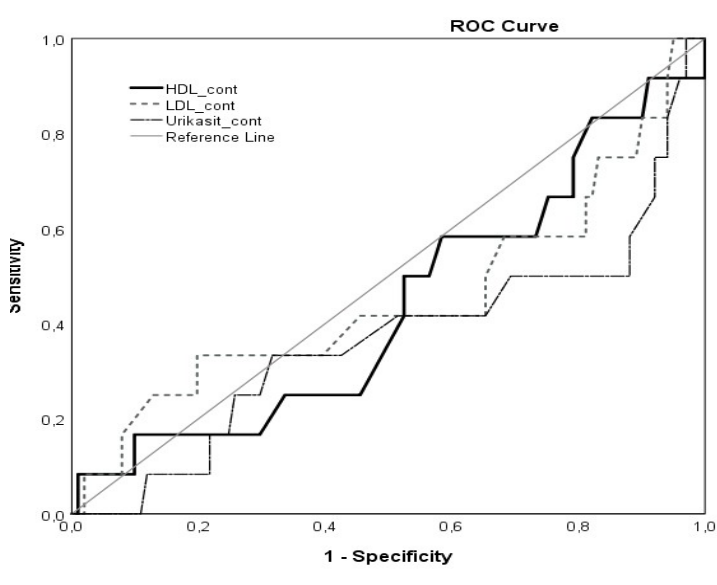

Figure 1. Correlation between LDL, HDL, and uric acid levels and 30-day mortality

HDL and LDL levels are insignificant factors. Additionally, multivariate analysis indicated that uric acid concentration was a protective factor for 30-day mortality, whereby increased uric acid concentration was found to decrease the risk of mortality and reduced uric acid concentration was found to increase the risk of mortality, which was consistent with the findings of numerous studies in the literature $(2,6)$.

Previous studies indicated that plasma lipoproteins neutralize lipopolysaccharides and lipoteichoic acid in gram- negative and positive bacteria. Therefore, it has been determined to play a role in body defense [12, 13]. Additionally, HDL has been reported to have anti-inflammatory, antioxidant, and immunomodulatory effects [14]. LDL, on the other hand, has been shown to facilitate the clearance of bacterial toxins in sepsis [15]. LDL and HDL levels are known to decrease in response to oxidation, infection, and inflammation [16]. Some previous studies evaluated patients hospitalized for CAP and indicated a strong correlation between reduced HDL concentration and causes of clinical

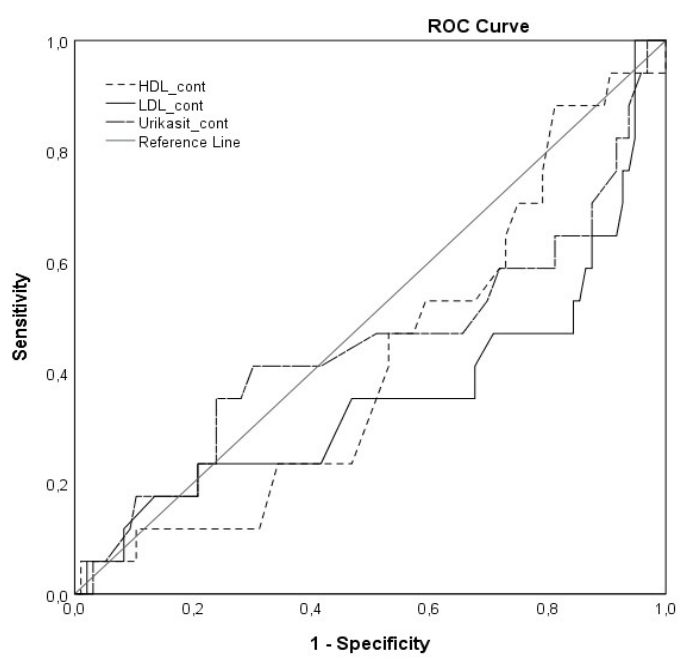

Figure 2. Correlation between LDL, HDL, and uric acid levels and ICU requirement

worsening such as hemodynamic instability and pleural effusion $[14,17]$.

In our study, initial serum HDL and LDL levels were found to be insignificant predictors of 30day prognosis and mortality. In the 17 patients with sepsis, serum lipid levels (cholesterol, $\mathrm{HDL}$, LDL) were assessed on admission and on days 3 and 28 after admission. The assessments indicated that lipoprotein concentrations decreased by $50 \%$, this reduction initially occurred in HDL concentration, and LDL concentration decreased more slowly compared to HDL concentration [18]. In our study, however, no reduction could be detected in LDL and particularly in HDL levels since no serial measurement was performed for any of these two parameters. Moreover, since no data was available regarding initial serum $\mathrm{HDL}$ and LDL levels in our patients, no comparison was achieved. Therefore our results were thought to be incompatible with the literature.

Uric acid, which is a product of purine metabolism, is excreted from the urine and 
gastrointestinal systems [19-21]. Therefore, kidney-function tests [glomerular filtration rate (GFR)] are one of the important factors affecting the uric acid level. Oxidative stress may alter serum uric acid concentration as a result of infection [22]. Additionally, reduced uric acid levels have been shown to be associated with the underlying malnutrition in patients [23]. A previous prospective study evaluated the effect of serum uric acid concentration on mortality in hospitalized in several ICUs and reported that elevated serum uric acid levels increased the mortality rate by 2.638 times. The authors suggested that serum uric acid level could be integrated into risk scoring systems through advanced studies [24, 25]. In our study, multivariate analysis indicated that serum uric acid concentration is a significant predictor of 30 -day mortality $(p=0.048)$. Additionally, serum uric acid concentration was also found to be a protective factor in CAP, whereby increased uric acid concentration was found to decrease the risk of mortality and reduced uric acid concentration was found to increase the risk of mortality by 1.44 times $(1 / 0.694)$. These findings of our study were consistent with those reported in the literature.

In the present study, initial serum uric acid levels were found to be an insignificant predictor of ICU requirement. Akbar et al. [21] evaluated hyperuricemia as an early marker of sepsis and they showed the APACHE II score correlates with increase uric acid level. Zhu and Cao [19] retrospectively found no correlation between initial uric acid levels and prognosis of infection in hospitalized ICU patients due to infection. It has been determined that serum uric acid levels vary due to changes in renal functions due to lactic acid deposition in severe infections [19, $26,27]$. In sepsis patients, in particular, lactic acid monitoring is of paramount importance. In the present study, however, no information could be obtained regarding the lactic acid levels of the patients due to the retrospective nature of the study. Moreover, the correlation between serum uric acid concentration and the severity assessment systems used in ICU could not be analyzed. Literature indicates that there is no consensus regarding the effect of serum uric acid concentration in predicting ICU requirement in hospitalized CAP patients. Our results were evaluated based on a small number of literature results.
Our study was limited in several ways. First, the study had a retrospective design and thus serum HDL, LDL, and uric acid levels of the patients were measured within the first $24 \mathrm{~h}$ after hospital admission. Accordingly, the serial measurements proposed in recent reports could not be performed and the relationship between serum uric acid concentration and the factors affecting this concentration such as body mass index (BMI), GFR, and serum glucose levels could not be analyzed due to the retrospective nature of the study. Second, the study was conducted in a single center, had a small patient population, and included no information regarding specific microbiological culture results and radiological outcomes of the patients. Based on we suggest that monitoring uric acid levels with serial measurements in patients with CAP may be useful for predicting the short term prognosis. Further prospective multicentric studies with larger patient series are needed to evaluate short-term mortality, microbiological and radiographic results, hemodynamic changes, and serial HDL and LDL measurements in CAP patients and also to investigate the correlation between these parameters and other acute-phase reactants.

Conflict of interest: No conflict of interest was declared by the authors.

\section{References}

1. Laurila A, Bloigu A, Nayha S, Hassi J, Leinonen M, Saikku P. Chronic Chlamydia pneumoniae infection is associated with a serum lipid profile known risk factor for atherosclerosis. Arterioscler Thromb Vasc Biol 1997;17:2910-2913. https://doi.org/10.1161/01. atv.17.11.2910

2. Gruber M, Christ Crain M, Stolz D, et al. Prognostic impact of plasma lipids in patients with lower respiratory tract infections-an observational study. Swiss Med Wkly 2009:139:166-172.

3. Nan H, Dong Y, Gao W, Tuomilehto J, Qiao Q. Diabetes associated with a low serum urıc acid level in a general Chinese population. Diabetes Res Clin Pract 2007;76:68-74. https://doi.org/10.1016/j. diabres.2006.07.022

4. Maiulo J, Oppedisano F, Gratteri S, Muscoli C, Mollace V. Regulation of uric acid metabolism and excreation. Int J Cardiol 2016;213:8-14. https://doi.org/10.1016/j. ijcard.2015.08.109

5. Temel MT, Demiryürek $\mathrm{S}$, Temel L, et al. Dynamic thiol/ disulfide homeostasis in children with communityacquired pneumonia. Pediatr Int 2019;61:252-257. https://doi.org/10.1111/ped.13773 
6. Lee HW, Choi SM, Lee J, et al. Serum uric acid level as a prognostic marker in patients with acute respiratory distress syndrome. J Intensive Care Med 2019;34:404410. https://doi.org/10.1177/0885066617698911

7. Rodriquez Reguerro JJ, Iglesias Cubero G, Vazquez $M$, et al. Variation in plasma lipid and lipoprotein concentrations in community-acquired pneumonia a six-month prospective study. Eur J Clin Chem Clin Biochem 1996;34:245-249. https://doi.org/10.1515/ cclm.1996.34.3.245

8. Kerttula $Y$, Weber T. Serum lipids in pneumonia of different aetiology. Ann Clin Res 1988;20:184-188.

9. British Thoracic Society Standarts of Care Committee. BTS Guidelines for the management of community acquired pneumonia in adults. Thorax 2001;56:1-64. https://doi.org/10.1136/thorax.56.suppl_4.iv1

10. Niederman MS, Mandell LA, Anzueto A, et al. American Thoracic Society. Guidelines for the management of adults with community-acquired pneumonia. Diagnosis, assessment of severity, antimicrobial therapy, and prevention. Am J Respir Crit Care Med 2001;163:17301754. https://doi.org/10.1164/ajrccm.163.7.at1010

11. Mandell LA, Wunderink RG, Anzueto A, et al. Infectious Diseases Society of America/America Thoracic Society consensus guidelines on the management of community-acquired pneumonia in adults. Clin Infect Dis 2007;44:27-72. https://doi.org/10.1086/511159

12. Pirillo A, Catapano AL, Norata GD. HDL in infectious diseases and sepsis. Handb Exp Pharmacol 2015;224:483-508. https://doi.org/10.1007/978-3-31909665-0_15

13. Viasus D, Rio Pertuz GD, Simonetti AF, et al. Biomarkers for predicting short-term mortality in community-acquired pneumonia: a systematic review and meta-analysis. J Infect 2016;72:273-282. https:// doi.org/10.1016/j.jinf.2016.01.002

14. Saballs M, Parra S, Sahun P, et al. HDL-c levels predict the presence of pleural effusion and the clinical outcome of community-acquired pneumonia. Springerplus 2016;5:1491. https://doi.org/10.1186/ s40064-016-3145-x

15. Guirgis FW, Donnelly JP, Dodani $S$, et al. Cholesterol levels and long-term rates of communityacquiredsepsis. Crit Care 2016;20:408. https://doi. org/10.1186/s13054-016-1579-8

16. Deniz O, Tozkoparan E, Yaman $\mathrm{H}$, et al. Serum HDL-C levels, log (TG/HDL-C) values and serum total cholesterol/HDL-C ratio significantly correlate with radiological extent of disease in patients with communityacquired pneumonia. Clin Biochem 2006;39:287-292. https://doi.org/10.1016/j.clinbiochem.2006.01.015

17. Kaysen GA, Ye X, Raimann J, et al. Lipid levels are inversely associated with infectious and allcause mortality: international MONDO study results. J Lipid Res 2018;59:1519-1528. https://doi. org/10.1194/jlr.P084277
18. Van Leeuwen HJ, Heezius ECJM, Dallinga GM, Van Strijp JAG, Verhoef J, Van Kessel KPM. Lipoprotein metabolism in patients with severe sepsis. Crit Care Med 2003;31:1359-1366. https://doi.org/10.1097/01. CCM.0000059724.08290.5

19. Zhu HC, Cao RL. The relationship between serum levels of uric acid and prognosis of infection in critically ill patients. World J Emerg Med 2012;3:186-190. https:// doi.org/10.5847/wjem.j.issn.1920-8642.2012.03.005

20. Mazzali M, Hughes J, Kim YG, et al. Elevated urıc acid increases blood pressure in the rat by a novel crystalindependent mechanism. Hypertension 2001;38:11011106. https://doi.org/10.1161/hy1101.092839

21. Akbar SR, Long DM, Hussain K, et al. Hyperuricemia: an early marker for severity for illness in sepsis. Int J Nephrol 2015;2015:301021. https://doi. org/10.1155/2015/301021

22. Giovannini I, Chiaria C, Giuliante F, et al. Biochemical and clinical correlates of hypouricemia in surgical and critically ill patients. Clin Chem Lab Med 2007;45:12071210. https://doi.org/10.1515/CCLM.2007.502

23. Tsai K, Hsu TG, Kong CW, Lin K, Lu FJ. Is the endogenous peroxyl-radical scavenging capacity of plasma protective in systemic inflammatory disorders in humans?. Free Radic Biol Med 2000;28:926-933. https://doi.org/10.1016/s0891-5849(00)00180-5

24. Iroezindu MO, Isiguzo GC, Chima El, et al. Predictors of in-hospital mortality and length of stay in communityacquired pneumonia: a 5-year multi-centre case control study of adults in a developing country. Trans R Soc Trop Med Hyg 2016;110:445-455. https://doi. org/10.1093/trstmh/trw057

25. Lim WS, van der Eerden MM, Laing $R$, et al. Defining community acquired pneumonia severity on presentation to hospital: an international derivation and validation study. Thorax 2003;58:377-382. https://doi. org/10.1136/thorax.58.5.377

26. Meneshian A, Bulkley GB. The physiology of endothelial xanthine oxidase: from urate catabolism to reperfusion injury to inflammatory signal transduztion. Microcriculation 2002;9:161-175. https://doi. org/10.1038/sj.mn.7800136

27. Ghiselli A, Serafini M, Natella F, Scaccini C. Total antioxidant capacity as a tool to assess redox statur: critical view and experiemntaldata. Free Radic Biol Med 2000;29:1106-1114. https://doi.org/10.1016/ s0891-5849(00)00394-4

The manuscript wit the title 'The Role Of Serum HDL, LDL, And Uric Acid Levels In Predicting The Prognosis Of CommunityAcquired Pneumonia' was partially presented at $23^{\text {th }}$ Turkish Thoracic Journal conference, October 15-18, 2020, Turkey. 
Ethics committee approval: Ufuk University Non-Interventional Clinical Research approved by the Ethics Committee (date: 16.12.2019 and number: 2019216/3).

\section{Contributions of the authors to the article}

D.H., E.E.A. set up the main idea anf hypothesis of the study. E.E.A., E.S.G. and N.O. developed the theory and edited the material method section. C.A. made the evaluation of data in results section. The discussion part of the article was written by D.H., B.A.K. and E.E.A. reviewed, made necessary corrections and approved. In addition, all authors diccussed the entire study and approved its final version. 